\title{
Influence of the vegetation management of the leeves in irrigated rice organic in diversity of Hymenoptera parasitoids
}

\author{
P. R. Simões-Pires ${ }^{a *}$, S. M. Jahnke ${ }^{a}$ and L. R. Redaelli ${ }^{a}$ \\ aPrograma de Pós-graduação em Biologia Animal, Universidade Federal do Rio Grande do Sul - UFRGS, \\ Av. Bento Gonçalves, 9500, CEP 91501-970, Porto Alegre, RS, Brazil \\ *e-mail: paola.simoesp@gmail.com
}

Received: April 11, 2015 - Accepted: May 25, 2015 - Distributed: August 31, 2016

(With 8 figures)

\begin{abstract}
Among the natural enemies of insect pests in rice fields, parasitoids are especially notable. To better understand the space-time dynamics of these insects, the objectives of this study were to describe and compare groups of parasitoids in organic irrigated rice fields using two management approaches for levee vegetation, and to relate them to the phenological stages of rice cultivation (the seedling, vegetative, and reproductive stages). The samples were taken in a plantation located in Viamão, RS, Brazil. The total area of 18 ha was divided into two parts: a no-cut (NC) subarea in which the wild vegetation of the levees was maintained, and a cut (C) subarea in which the levee vegetation was cut monthly. In each subarea, four Malaise traps considered as pseudo-replicas were installed and remained in the field for 24 hours at each sampling location. Collections occurred twice a month from the beginning of cultivation (October 2012) until harvest (March 2013). A total of 3,184 Hymenoptera parasitoids were collected: 2,038 individuals in the NC subarea and 1,146 in the C subarea. We identified 458 morphospecies distributed in 24 families. Mymaridae was the most abundant and Eulophidae was the richest in both subareas. A total of 198 morphospecies was shared between the subareas, including Platygastridae, Eulophidae, and Mymaridae, which were the families with the highest number of shared species. The richness and abundance of parasitoids varied according to their phenological developmental stages, with peak abundance registering during the vegetative period. The Morisita index identified three groupings, indicating a similarity that was related to the three phases of rice growth and development: seedling, vegetative and post-harvest.
\end{abstract}

Keywords: Oryza sativa, conservational biological control, habitat management.

\section{Influência do manejo da vegetação das taipas em arroz orgânico irrigado na diversidade de himenópteros parasitoides}

\section{Resumo}

Entre os inimigos naturais de insetos pragas em campos de arroz, parasitoides são especialmente notáveis. Para melhor entender a dinâmica espaço-temporal destes insetos, os objetivos desse estudo foram descrever e comparar os grupos de parasitoides em campos de arroz orgânico irrigado utilizando duas abordagens de manejo da vegetação das taipas, e relacioná-los com os estádios fenológicos da cultura (plântula, vegetativo e reprodutivo). As amostragens foram realizadas em uma plantação localizada em Viamão, RS. A área total de 18 ha foi dividida em duas partes: uma subárea não roçada (NR) na qual a vegetação espontânea das taipas foi mantida, e uma roçada (R) subárea em que a vegetação das taipas foi roçada mensalmente. Em cada subárea, quatro armadilhas Malaise consideradas pseudo-réplicas foram instaladas e mantiveram-se no campo durante 24 horas, em cada local de amostragem. As coletas ocorreram duas vezes por mês, desde o início do cultivo (outubro de 2012) até a colheita (março de 2013). Um total de 3.184 himenópteros parasitoides foram coletados: 2.038 indivíduos na subárea NR e 1.146 na R. Foram identificadas 458 morfoespécies, distribuídas em 24 famílias. Mymaridae foi a mais abundante e Eulophidae a mais rica para ambas as subáreas. Um total de 198 morfoespécies foi compartilhado entre as subáreas, incluindo Platygastridae, Eulophidae e Mymaridae, que foram as famílias com o maior número de espécies compartilhadas. A riqueza e a abundância de parasitoides variou de acordo com as fases de desenvolvimento fenológico da cultura, com pico de abundância registrado no período vegetativo. O Índice de Morisita identificou três grupamentos indicando uma similaridade relacionada às fases da cultura, plântula, vegetativo e, na pós-colheita.

Palavras-chave: Oryza sativa, controle biológico conservativo, manejo do habitat. 


\section{Introduction}

Rice (Oryza sativa L.) can be cultivated in highlands, as it is suitable for flooding, and it can also be cultivated in stormwater plains (Bambaradeniya and Amerasinghe, 2003); however, more than $75 \%$ of rice production is from an irrigated crop system (Pereira et al., 2005). In Brazil, the irrigated rice agroecosystem is responsible for approximately $70 \%$ of the national production (Beutler, 2013).

The rice cycle can be divided into three stages: vegetative (from emergence to panicle differentiation), reproductive (from panicle differentiation to anthesis), and grain filling (from anthesis to physiological maturity) (Infeld et al., 1998). In these different stages, the crop can be attacked by many insects that are considered pests, which subsequently cause damage (Oliveira et al., 2010).

Irrigated rice farms (as compared to those for other crops) are environments that facilitate the maintenance of high levels of biodiversity since they are surrounded by aquatic and terrestrial habitats. Pest insects are present in rice production areas all over the world, especially in irrigated crop systems and in stormwater plains, which present temperatures and humidity levels favorable for their proliferation (Yasumatsu and Torh, 1968). In order to control pests, many methods can be used to implement agroecosystems that are economically and ecologically sustainable, thus creating opportunities to increase the abundance and efficiency of many natural enemies (Bueno and Van Lenteren, 1999). One of these methods includes employing conservation biological control, which aims through habitat management - to turn to available alternative food, such as nectar, pollen, and honeydew. It also aims to provide shelter and a moderate microclimate, thus protecting natural enemies from extreme environmental conditions, while creating habitats for their alternative preys and hosts (Landis et al., 2000). Parasitoids are perhaps the most notable natural enemies, and they are constituted mainly by insects of the Hymenoptera and Diptera orders (Gullan and Cranston, 2008). In rice crops, the main parasitoids are the microhymenopteran, which are similar to small wasps that have a preference for putting their egg masses in caterpillars' bodies and aphids (Freitas et al., 2010).

The preservation and maintenance of parasitoids, according to Bueno (2005), is essential to the balance of the agricultural system, as well as to the reduction of production costs. Studies that approach parasitoid ecology and its relation to vegetable species in areas surrounding the crop are fundamental to the conservation management practices that may be implemented. In this context, this work aimed to identify, quantify, and compare the richness and abundance indicators of the parasitica hymenoptera assemblage in organic irrigated rice crops under two management systems of wild vegetation, as related to the crop's phenological stages.

\section{Material and Methods}

This study was performed in an area that is part of the Movements of Landless Rural Workers Settlement "Filhos de Sepé" ( $30^{\circ} 03^{\prime}$ S, 50 $52^{\circ}$ 'W) located in the
Environmental Protection Area (APA) Banhado Grande, in the Águas Claras district, in Viamão, RS, Brazil. Given that they are located within an Environmental Protection Area, these rice plantations have been managed with organic practices since 2007 , and the cooperative of producers has been using the "Organic Product Brazil" stamp (COOPAN, 2014).

The sample area, which was approximately 18 ha and planted with cultivar Epagri 108, was subdivided in two subareas separated by an access road. Each subarea comprised about 15 frames of approximately $6,000 \mathrm{~m}^{2}$, delimited by earth levees to ensure the maintenance and management of water for rice flooding. In one of the subareas, the wild vegetation from the levees was cut (C) on a monthly basis since the beginning of the planting period, in October until the harvest, in March; in the other subarea, the wild vegetation was not cut (NC). Considering the difficulty in find more three similar areas with the same size (18 ha) and conditions, we have decided evaluate the date, in each subarea, through four pseudo-replicas in the leeves of two frames (Figure 1). To collect the hymenopteran parasitoids, four Malaise traps were installed twice a month during a period of 24 hours in the levees that surrounded the frames at both the $\mathrm{NC}$ site and the $\mathrm{C}$ site in each subarea. The collected insects were stored in $70 \%$ alcohol, labeled with the sampling point and trap, and transported to the Insect Biology, Ecology, and Biological Control Laboratory (BIOECOLAB) at the Plant Health Department of the Federal University of Rio Grande do Sul (UFRGS).

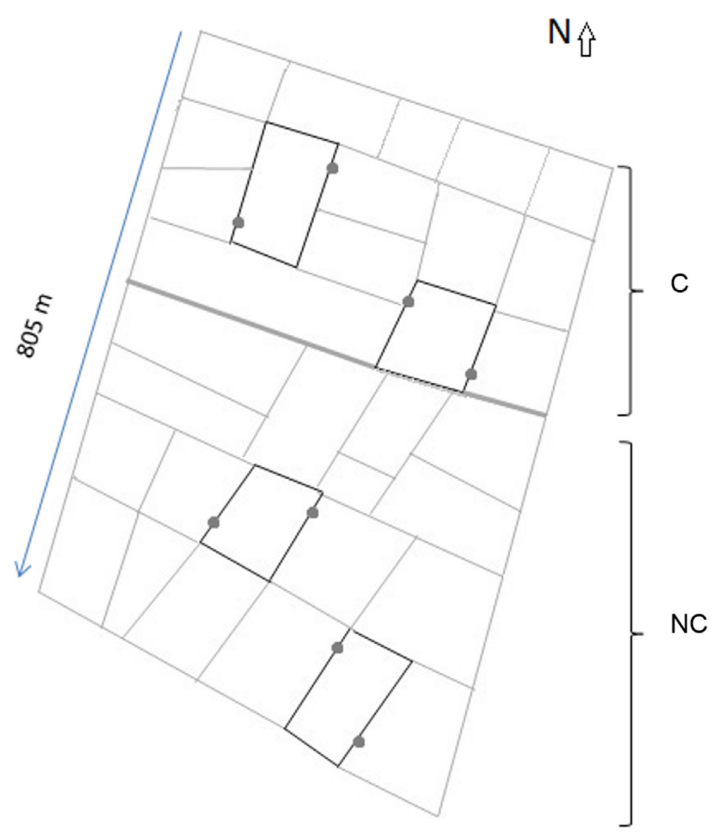

Figure 1. Sketch showing the two sub-areas (wild vegetation from the levees cut (C) and no cut -NC) with the chosen frames and points of placement of Malaise traps (pseudo-replicas) in Viamão, RS, Brazil. 
The collections began from the rice planting date (by the end of October 2012) and were extended until the postharvest (in March 2013), when the last collection was made. At each sampling occasion, the crop development stage was registered, following the categories proposed by Counce et al. (2000): the seedling stage - from sowing until plant emergence; the vegetative stage - from emergence until the appearance of the last leaf collar (flag leaf) on the main stem; and the reproductive stage - from the start of reproductive structure differentiation (panicle) until physiological maturity (all panicle spikelets with a brown husk).

The insects were separated into morphospecies under a Nikon SMZ445 stereomicroscope. Families of Hymenoptera were identified following the classification system adopted by Goulet and Huber (1993) and Costa (2004). For identification at a specific level, the samples were submitted to specialists of the different groups. The specimens were deposited in a reference collection, BIOECOLAB.

Meteorological data for the mean daily temperature and monthly rainfall were obtained from Brazil's National Meteorological Institute (INMET, 2013).

The average number of hymenopteran parasitoid individuals collected at each sampling occasion were compared between sampling sites, and the rice stages were compared using analysis of variance (ANOVA) (the Kruskal-Wallis test) (Hammer et al., 2001) with a significance level of 5\% .

Biological diversity was analyzed with the ShannonWiener (H'), Simpson (1-D), Margalef (DMg) indices and compared between sampling sites at each rice stages, using Past software, version 2.10 (2011) (Hammer et al., 2001).
Alpha diversity was measured by rarefaction method, which calculates the expected number of species in each sample. These have been standardized by the smaller sample, then comparing the differences between the two areas (Gotelli and Colwell, 2001). The species accumulation curve, estimators and rarefaction curves were adjusted by EstimateS 8.2.0 software (Colwell, 2009).

The species composition (Beta diversity) was compared between the subareas and crop stages using cluster analysis (the UPGMA algorithm with Morisita's index). To detail the taxa that held greater importance between the subareas, a similarity percentage analysis (SIMPER) was performed (Clarke and Warwick, 2001) in which the similarity matrices were built using the Bray-Curtis coefficient via the Past software (Hammer et al., 2001). Qualitative differences were demonstrated through a Venn diagram, distinguishing the exclusive and shared morphospecies between the subareas.

\section{Results}

A total of 2,038 individuals of parasitoid wasps was collected from the NC subarea and 1,146 were collected from the $\mathrm{C}$ subarea. The average number of collected individuals by trap and sampling occasion was significantly larger in the $\mathrm{NC}$ area $(42.5 \pm 12.9)$ than in $\mathrm{C}$ area $(23.9 \pm 7.2)$ $(\mathrm{H}=7.0687$; $\mathrm{p}<0.05)$.

Mymaridae was the most abundant family, with 914 individuals captured in both subareas (28.7\%), followed by Platygastridae with 550 individuals (17.2\%) and Encyrtidae with 333 (10.4\%). Even though the abundance pattern was similar for both management methods, the number of individuals was always higher in the $\mathrm{NC}$ at each sampling point (Figure 2).

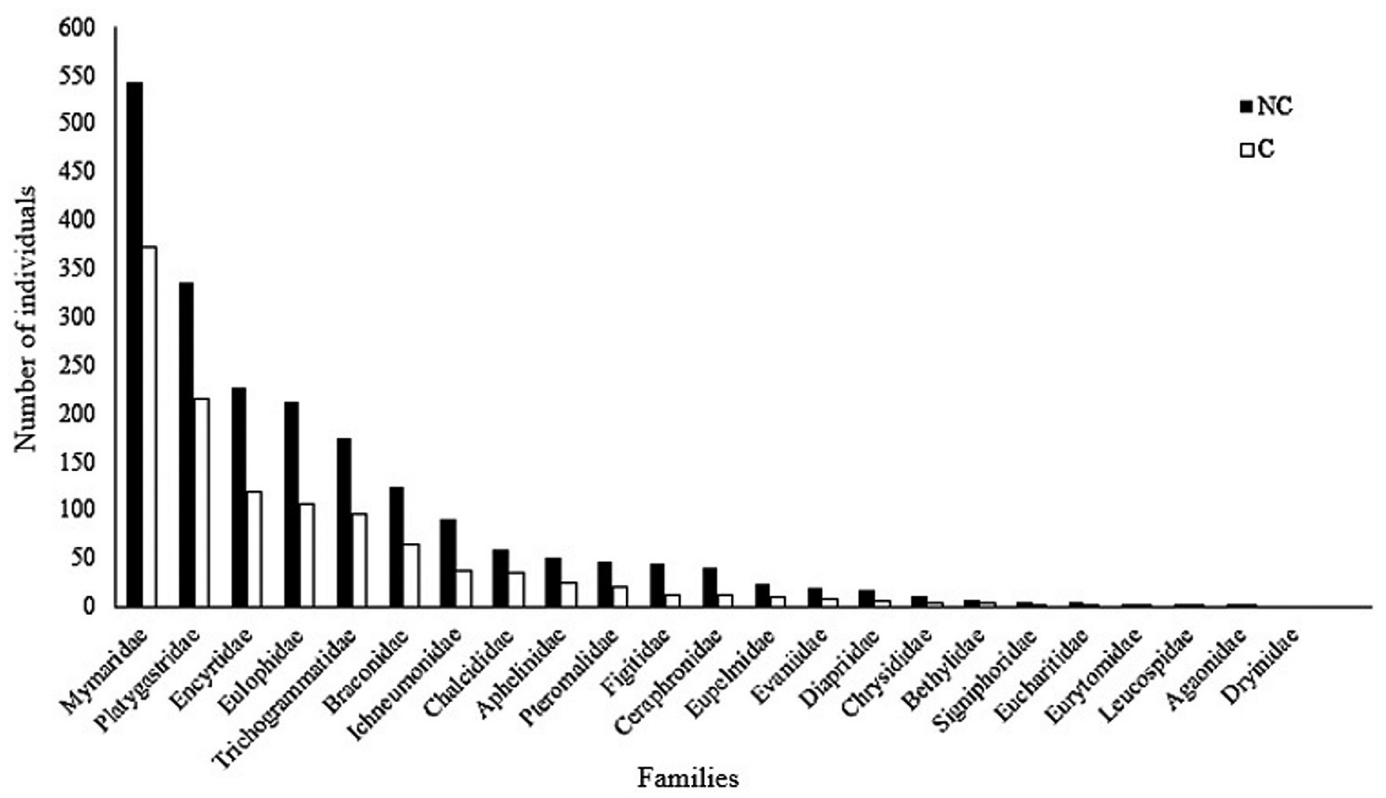

Figure 2. Abundance of hymenopteran parasitoids families in irrigated rice in organic system of production, in subareas not cut (NC) and cut (C) recorded between October/2012 to March/2013, Viamão, RS, Brazil. 
We identified a total of 458 morphospecies, from which 198 were shared between both subareas (Figure 3).

We registered 401 morphospecies in the NC subarea and 253 in the $\mathrm{C}$ subarea. Eulophidae was the richest family (60 in NC and 44 in C) in both areas, followed by Platygastridae (57 in $\mathrm{NC}$ and 43 in C). Ichneumonidae was the third-richest family in the NC subarea (number $[n]=51$ ), while in the $C$ subarea, Braconidae was the third most abundant ( $\mathrm{n}=25)$ (Figure 4).

In the NC subarea 179 singletons, 66 doubletons, 199 unicates, and 79 duplicates were observed; in the C subarea, 116 singletons, 48 doubletons, 132 unicates, and 54 duplicates were also noted. The estimated richness in the NC subarea, as determined by the Bootstrap, Jack 1, and Chao 1 estimators, indicated that $83.2 \%, 68.7 \%$, and $62.7 \%$ of the species, respectively, were sampled (Figure 5). In subarea $\mathrm{C}$, the same estimators indicated that $82.5 \%$, $67.5 \%$, and $64.9 \%$ of the species were sampled (Figure 6).

The rarefaction curve, which plotted the registered number of morphospecies in relation to the number of collected individuals (Figure 7), showed that there are differences between the subareas. At the cutoff point (around 1,200 individuals), the richness observed in subarea $C$ was not under the $95 \%$ confidence limit of the rarefaction curve in the $\mathrm{NC}$ region, which shelters a larger assemblage.

The diversity indices showed differences between subareas at phenological stages of rice (Table 1).

The dendrogram, developed from Morisita's index (Figure 8), generated three clusters with similarity levels greater than $75 \%$. These clusters are related to crop stage: the seedling, vegetative, and postharvest stages, respectively. Thus, we can consider that although the diversity was generally greater in the NC subarea, much of the similarity noted between the subareas studied was associated with the stages of crop development, especially since the clusters were related to these stages.

\section{Discussion}

The greatest number of Hymenoptera parasitoids caught in subarea NC was expected and shows the importance of the wild vegetation as an alternative habitat in irrigated rice, as it provides different resources throughout the crop

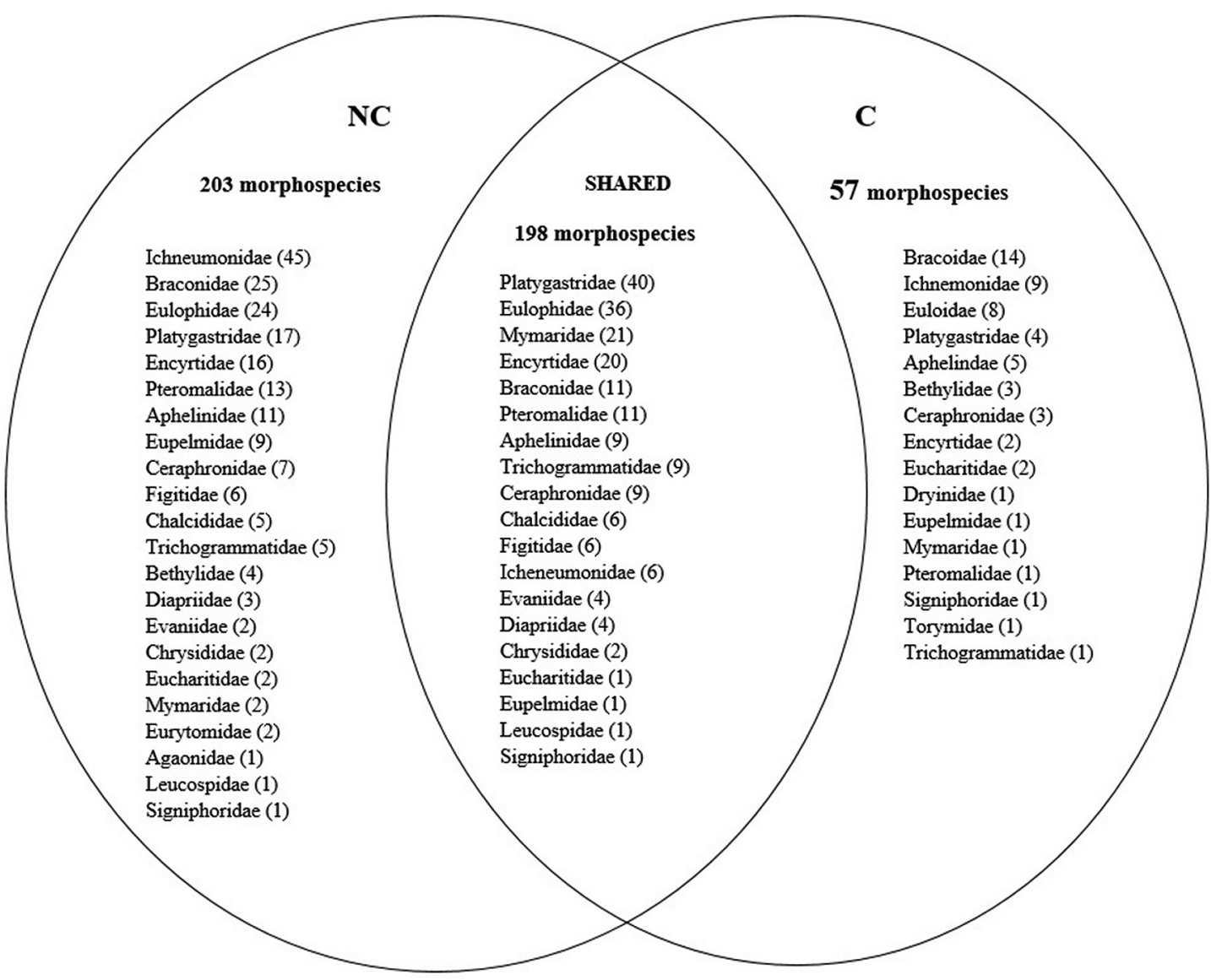

Figure 3. Venn diagram showing the composition of parasitoid hymenopteran morphospecies distributed among families, exclusive and shared, collected in subarea not cut (NC) and cut (C), between October/2012 to March/2013 in Viamão, RS, Brazil. 
cycle (Landis et al., 2000; Gurr et al., 2003). This result corroborate Altieri et al. (2003) studies whose demonstrated that wild vegetation surround the crops can increase the number and diversity of natural enemies.

Mymaridae species, which was most abundant in this study, are egg parasitoids of Hemiptera, Coleoptera, and Diptera, which are deposited in hidden places like the inner tissue of plants, shells, and soil cavities (Souza et al., 2006). In this way, the abundance of this family can be associated with the existence of a large number of potential hosts in rice crop. Bambaradeniya and Edirisinghe (2008) also found a higher abundance of this family (39\%) in irrigated rice in Sri Lanka, which was associated with planthoppers' eggs, Nilaparvata lugens (Stål, 1854) and Sogatella

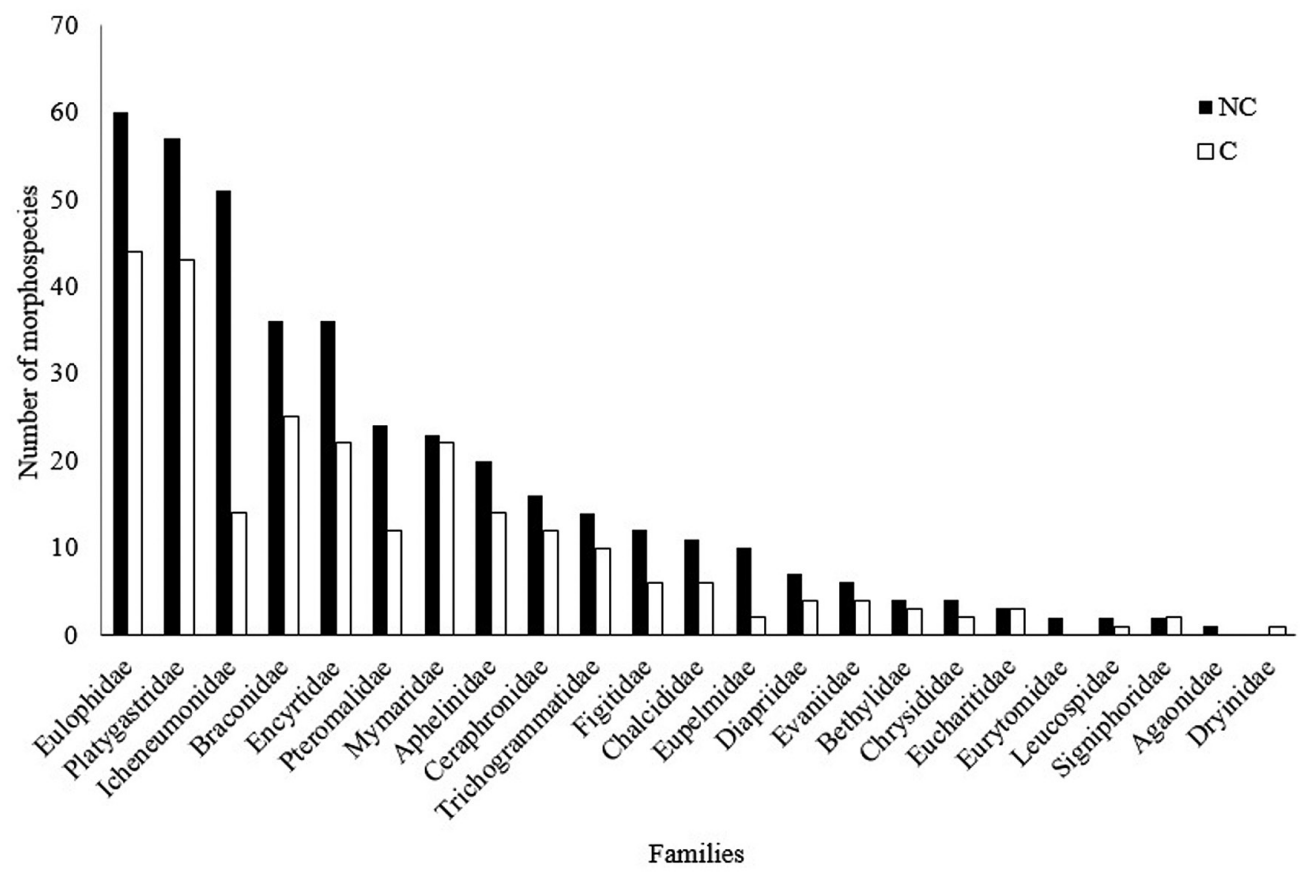

Figure 4. Morphospecies richness of hymenopteran parasitoids families in irrigated rice in organic system of production, in subareas not cut (NC) and cut (C) recorded between October/2012 to March/2013, Viamão, RS, Brazil.

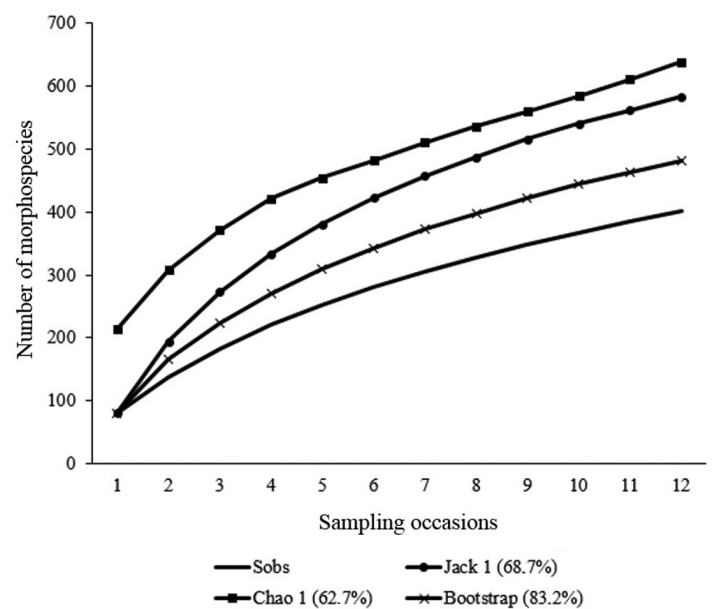

Figure 5. Curve sampling sufficiency (observed richness - Sobs) and estimated richness by Chao 1, Jacknife 2 and Bootstrap of hymenopteran parasitoids (randomized 500 times) sampled from irrigated rice in organic system of production, in subarea not cut (NC), between October/2012 to March/2013, Viamão, RS, Brazil.

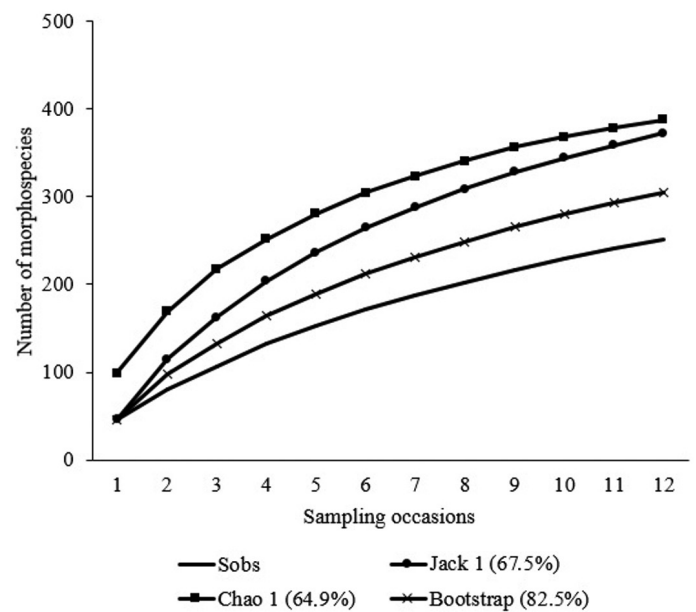

Figure 6. Curve sampling sufficiency (observed richness - Sobs) and estimated richness by Chao 1, Jacknife 2 and Bootstrap of hymenopteran parasitoids (randomized 500 times) sampled from irrigated rice in organic system of production, in subarea cut (C), between October/2012 to March/2013, Viamão, RS, Brazil. 


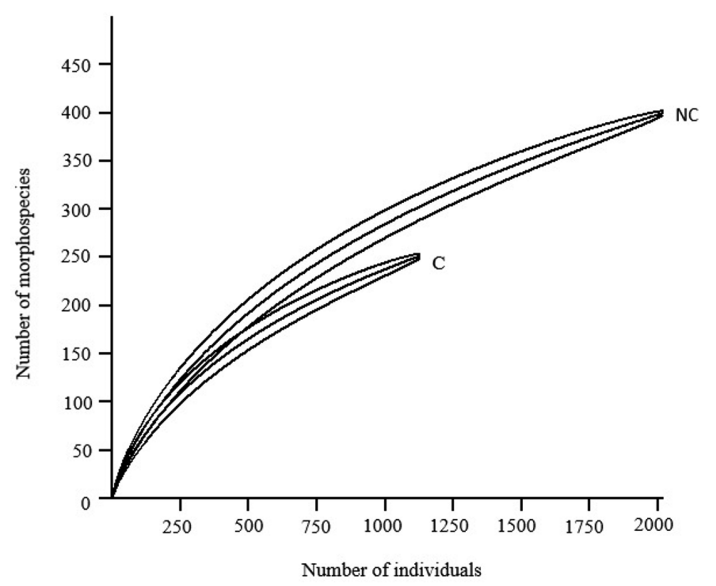

Figure 7. Comparative richness rarefaction curves of hymenopteran parasitoids morphospecies collected in irrigated rice in organic system of production, in subareas not cut (NC) and cut (C) between October/2012 to March/2013 in Viamão, RS. furcifera (Horváth, 1899) (Hemiptera: Delphacidae), which are important pests in that region. Even though these planthoppers are not listed as pests in Brazil, others like Tagosodes orizicolus (Muir, 1926) (Hem.: Delphacidae), Graphocephala sp., and Estianus sp. (Hem.: Cicadellidae) are registered for rice (Didonet et al., 2001), and their eggs can be parasitized by species of Mymaridae.

As expected, the NC subarea presented a higher richness of exclusive individuals, since the wild vegetation can contribute to the increased abundance and diversity of natural enemies, in addition to providing fundamental ecological services, as reported by Landis et al. (2000).

Eulophidae, with the greatest number of morphospecies in both subareas, includes parasitoid species associated with important agricultural pests (Hansson, 2004) such as the fall armyworm, Spodoptera frugiperda (J. E. Smith, 1797) (Lep.: Noctuidae), a polyphagous insect that causes great damage to rice crops (Ferreira and Barrigossi, 2004). There were also registers of Eulophidae individuals parasitizing Odonata eggs (Fursov and Kostyukov, 1987),

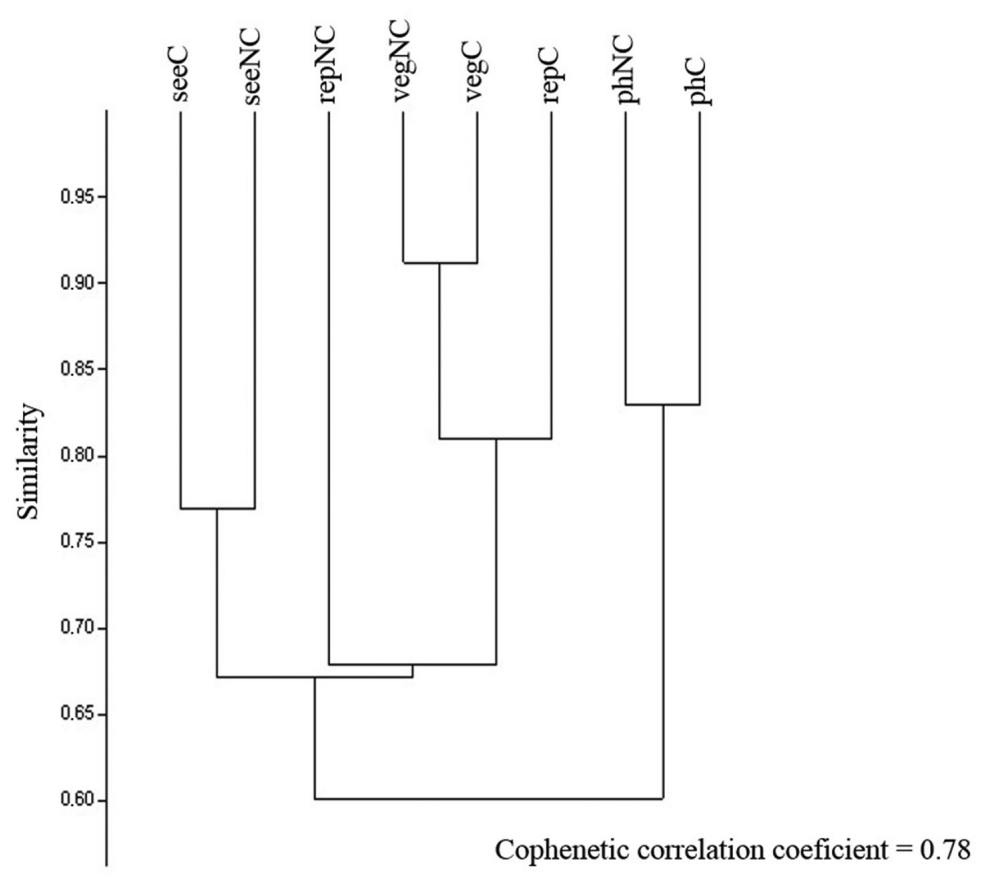

Figure 8. UPGMA cluster analysis of similarity (Morisita index) to hymenopteran parasitoids collected in Subarea NC and C, between October/2012 to March/2013 Viamão, RS. Correlation coefficient cophenetic $r c=0.78$. seeNC $=$ seedling stage in Subarea $\mathrm{NC}$, seeC $=$ the seedling stage in Subarea $\mathrm{C}$, vegNC = vegetative stage in Subarea $\mathrm{NC}$, vegC $=$ vegetative stage in Subarea $\mathrm{C}=$ repNC reproductive stage in Subarea $\mathrm{NC}, \mathrm{repC}=$ reproductive stage in Subarea $\mathrm{C}$, phNC $=$ postharvest subarea $\mathrm{NC}, \mathrm{phC}=$ postharvest subarea $\mathrm{C}$.

Table 1. Values of Margalef (DMG), Shannon-Wiener index (H') and Simpson's index (1-D) of hymenopteran parasitoids for not cut subarea (NC) and cut (C) at phenological stages of rice between October/2012 to March/2013.

\begin{tabular}{|c|c|c|c|c|c|c|c|c|c|c|c|c|}
\hline & \multicolumn{3}{|c|}{ Seedling } & \multicolumn{3}{|c|}{ Vegetative } & \multicolumn{3}{|c|}{ Reproductive } & \multicolumn{3}{|c|}{ Postharvest } \\
\hline & $\mathrm{NC}$ & $\mathrm{C}$ & Boot & $\mathrm{NC}$ & $\mathrm{C}$ & Boot & $\mathrm{NC}$ & $\mathrm{C}$ & Boot & $\mathrm{NC}$ & $\mathrm{C}$ & Boot \\
\hline DMG & 28.5 & 21.33 & 0.002 & 35.1 & 24.94 & 0.001 & 26.91 & 12.27 & 0.001 & 17.51 & 14.31 & 0.016 \\
\hline $\mathbf{H}^{\prime}$ & 4.42 & 4.11 & 0.021 & 4.56 & 4.33 & 0.112 & 4.49 & 3.69 & 0.001 & 4.08 & 3.81 & 0.05 \\
\hline 1-D & 0.972 & 0.966 & 0.134 & 0.973 & 0.973 & 0.992 & 0.978 & 0.96 & 0.019 & 0.969 & 0.957 & 0.202 \\
\hline
\end{tabular}


a group frequently found in this system, favored by areas that stay flooded for a long period throughout the year.

The other families that exhibited great abundance in this work - specifically, Ichneumonidae and Braconidae - also presented with species that parasitize important pests related to rice, like the fall armyworm (S. frugiperda) parasitized by Campoletis flavicicta (Ashmead, 1890) (Hym.: Ichneumonidae) (Dequech et al., 2004), and Diatraea saccharalis (Fabricius, 1794) (Lepidoptera: Pyralidae), parasitized by Apanteles flavipes (Cameron, 1891) (Hym.: Braconidae) (Ferreira et al., 2001). According to Askew (1971), the young forms of Lepidoptera are the most frequent hosts of the ichneumonid and braconid species.

Platygastridae was also a family with great abundance of individuals. This family has important parasitoids of rice pests like Oebalus poecilus (Dallas) (Hem.: Pentatomidae) that can overwinter, when the rice is not in the field, in bamboo litter or grass clumps (Santos et al., 2006).

Based on species accumulation curves (Sobs) of both subareas, the total richness was not sampled (Figures 5 and 6). This must have occurred because, among other factors, the samples had been restricted to the rice cycle period. In both subareas, the quantity of singletons was high, for this reason, the Chao 1 estimator, exceeds the species richness observed. Chao 1 estimator will exceed observed richness by ever greater margins as the relative frequency of singletons increase (Magurran, 2011). On the other hand, according to the Bootstrap estimator, in both subareas, $82 \%$ of the species was sampled, as based on the species incidence and using the unicate and duplicate numbers for richness estimates.

The architecture of plants in different developmental stages may have also affected the richness and abundance of the species. According to Lawton (1983), during the plants' development, the presence of leaves, sprouts, flowers, and fruit changes their architecture, influencing the phytophagous insects' diversity and, consequently, their natural enemies.

Although the richness differed between subareas, we can observe that the diversity pattern was similar, which is partially explained by the high quantity of shared morphospecies. This was confirmed by the SIMPER analysis, in which the Mymaridae and Encyrtidae taxa contributed to the sample similarity. Morphospecies from these two families showed up in both subareas with a higher frequency in relation to the others. The biggest differences occurred during the reproductive stage, possibly due to the richness of the $\mathrm{NC}$ subarea at this stage, which was quite different from the richness in the $\mathrm{C}$ area. The observed richness may be related to the wild vegetation present there, which offers fundamental ecological resources to the parasitoids (Menezes, 2006), thus favouring the action of this vegetation on the possible pests found in that region.

Parasitoids were present throughout all of the developmental cycles of the rice crops, but their diversity varied in relation to crop stage. The vegetative stage presented with higher levels of parasitoid richness, showing the possible action of these pests during an important period for the crop, in which a larger number of pest insects showed up during paddy cultivation (Fritz et al., 2008).

The Margalef index showed greater diversity in subarea $\mathrm{NC}$ in all stages of development, which was expected since this index associated the number of species recorded with the total number of sampled individuals (Magurran, 2011), considering that both the richness and the abundance of individuals were higher in this subarea. The Shannon index showed significant differences in the seedling, reproductive and post-harvest stages, however, in vegetative this was not observed. The lack of difference could be by the fact that this is one evenness index, which considers the uniformity of the dominant species abundance distributions of all species through the sample and (Moreno, 2001), during this period, the proportion of dominant species was similar between subareas. For the Simpson index, diversity differed only in the reproductive stage, showing that in the other plant stages, the distribution pattern of species abundance was similar between subareas.

A more diverse assembly in the NC levee subarea was expected given that no other aspect of agricultural systems provides such fundamental ecological services to ensure the protection of crops against pest insects as vegetation diversity (Altieri et al., 2003).

In this way, we consider that attempts to implement methods for pest management in agroecosystems, which are based on ecological principals that aim to increase diversity, should take into account the maintenance or incorporation of plant species that offer multiple functions, such as the maintenance of natural enemy populations (Altieri et al., 2003) which, in rice crops, can be reached by conserving levees wild plants.

\section{Acknowledgements}

Acknowledgements to the farmer Clairton Neres for attention and for allowing the study area. To CAPES and CNPq for scholarships to the first and third authors, respectively.

\section{References}

ALTIERI, M.A., SILVA, E.M. and NICHOLLS, C.I., 2003. $O$ papel da biodiversidade no manejo de pragas. Ribeirão Preto: Holos. 226 p.

ASKEW, R.R., 1971. Parasitic insects. London: Heinemann Educational Books. 316 p.

BAMBARADENIYA, C.N.,B. and AMERASINGHE, F.P., 2003. Biodiversity associated with the rice field agro-ecosystem in Asian countries: a brief review. Colombo: International Water Management Institute. 24 p. Working Paper, vol. 63.

BAMBARADENIYA, C.N.B. and EDIRISINGHE, J.P., 2008. Composition, structure and dynamics of arthropod communities in a rice agro-ecosystem. Ceylon Journal of Science, vol. 37, pp. 23-48.

BEUTLER, A.N., 2013 [viewed 22 January 2014]. Plantio direto de arroz irrigado por inundação é viável [online]. Available from: http://www.diadecampo.com.br/zpublisher/materias/Materia. asp? $\mathrm{id}=29249 \&$ secao $=$ Artigos

BUENO, V.H.P. and VAN LENTEREN, J.C.V., 1999. The popularity of augmentative biological control in Latina America: history and 
state of affairs. In: Proceedings of the lst International Symposium on Biological Control of Arthropods, 1999, Honolulu, Hawaii. Washington: USDA Forest Service, pp. 180-184.

BUENO, V.H.P., 2005. Controle biológico aumentativo com agentes entomófagos. In: M. VENZON, T.J. PAULA JÚNIOR and A. PALLINI, eds. Controle alternativo de doenças e pragas. Viçosa: EPAMIG, pp. 23-42.

CLARKE, K.R. and WARWICK, R.M., 2001. Changes in marine communities: an approach to statistical analysis and interpretation. 2nd ed. Plymouth: PRIMER-E.

COLWELL, R.K., 2009 [viewed 22 January 2014]. EstimateS: statistical estimation of species richness and shared species from samples. v. 8.2.0 [online]. Connecticut: University of Connecticut. Available from: http:// viceroy.eeb.ucon.edu/estimates

COOPERATIVA DE PRODUÇÃO AGROPECUÁRIA NOVA SANTA RITA - COOPAN, 2014 [viewed 26 February 2014]. [online]. Nova Santa Rita. Available from: http://www.coopanrs. com.br/produtos-arroz.php

COSTA, V.A., 2004. Identificação de famílias de himenópteros parasitoides. Campinas: Arquivos do Instituto Biológico. 34 p.

COUNCE, P., KEISLING, T.C. and MITCHELL, A.J., 2000. A uniform, objective, and adaptative system for expressing rice development. Crop Science, vol. 40, no. 2, pp. 436-443. http:// dx.doi.org/10.2135/cropsci2000.402436x.

DEQUECH, S.T.B., SILVA, R.F.P. and FIUZA, L.M., 2004. Ocorrência de parasitoides de Spodoptera frugiperda (J. E. Smith) (Lep.: Noctuidae) em lavouras de milho em Cachoeirinha, RS. Santa Maria. Ciência Rural, vol. 34, no. 4, pp. 1235-1237. http:// dx.doi.org/10.1590/S0103-84782004000400042.

DIDONET, J., DIDONET, A.P.P., ERASMO, E.L. and SANTOS, G.R., 2001. Incidência e densidade populacional de pragas e inimigos naturais em arroz de terras altas, em Gurupi-TO. Bioscience Journal, vol. 17, pp. 67-76.

FERREIRA, E. and BARRIGOSSI, J.A.F., 2004 [viewed 26 February 2014]. Cultivo do Arroz Irrigado no Estado do Tocantins [online]. Brasília: Embrapa Arroz e Feijão. Available from: http:// sistemasdeproducao.cnptia.embrapa.br/FontesHTML/Arroz/ ArrozIrrigadoTocantins/index.htm

FERREIRA, E., BARRIGOSSI, J.A.F. and VIEIRA, N.R.A., 2001. Percevejo das panículas do arroz: fauna Heteroptera associada ao arroz. Santo Antônio de Goiás: Embrapa Arroz e Feijão. 27 p.

FREITAS, T.F.S., OLIVEIRA, J.V. and FIUZA, L., 2010. Inimigos naturais em arroz irrigado. Lavoura Arrozeira, vol. 58, pp. 20-22.

FRITZ, L.L., HEINRICHS, E.A., PANDOLFO, M., SALLES, S.M., OLIVEIRA, J.V. and FIUZA, L.M., 2008. Agroecossistemas orizícolas irrigados: insetos praga, inimigos naturais e manejo integrado. Oecologia Brasiliensis, vol. 12, pp. 720-732.

FURSOV, V.N. and KOSTYUKOV, V.V., 1987. New species of the genus Tetrastichus (Hymenoptera, Eulophidae), egg parasites of damselfies and dragonflies and of predaceous diving beetles. Zoologichesky Zhurnal, vol. 66, pp. 217-228.

GOTELLI, N.J. and COLWELL, R.K., 2001. Quantifying biodiversity: procedures and pitfalls in the measurement and comparison of species richness. Ecology Letters, vol. 4, no. 4, pp. 379-391. http://dx.doi.org/10.1046/j.1461-0248.2001.00230.x.

GOULET, H. and HUBER, J.T., 1993. Hymenoptera of the World: an identification guide to families. Ottawa: Agriculture Canada Publication. 668 p.

GULLAN, P.J. and CRANSTON, P.S., 2008. Os insetos: um resumo de entomologia. São Paulo: Roca. 400 p.
GURR, G.M., WRATTEN, S.D. and LUNA, J.M., 2003. Multifunction agricultural biodiversity: pest management and other benefits. Basic and Applied Ecology, vol. 4, no. 2, pp. 107-116. http://dx.doi.org/10.1078/1439-1791-00122.

HAMMER, O., HARPER, D.A.T. and RYAN, P.D., 2001. PAST: paleontological statistics software package for education and data analysis. Palaeontologia Electronica, vol. 4, no. 1, pp. 1-9.

HANSSON, C., 2004. Eulophidae of Costa Rica (Hymenoptera: Chalcidoidea). Gainesville: American Entomological Institute. Memoirs of the American Entomological Institute, no. 2.

INFELD, J.A., SILVA, J.B. and ASSIS, F.N., 1998. Temperaturabase e graus-dia durante o período vegetativo de três grupos de cultivares de arroz irrigado. Santa Maria. Revista Brasileira de Agrometeorologia, vol. 6, pp. 187-191.

INSTITUTO NACIONAL DE METEREOLOGIA - INMET, 2013 [viewed 5 December 2013]. Estações e dados [online]. Brasília. Available from: http://www.inmet.gov.br

LANDIS, D.A., WRATTEN, S.D. and GURR, G.M., 2000. Habitat management to conserve natural enemies of arthropod pests in agriculture. Annual Review of Entomology, vol. 45, no. 1, pp. 175-201. http://dx.doi.org/10.1146/annurev.ento.45.1.175. PMid:10761575.

LAWTON, J.H., 1983. Plant architecture and the diversity of phytophagous insects. Annual Review of Entomology, vol. 28, no. 1, pp. 23-39. http://dx.doi.org/10.1146/annurev.en.28.010183.000323.

MAGURRAN, A.E., 2011. Medindo a diversidade biológica. Curitiba: Editora da UFPR. 261 p.

MENEZES, E.L.A., 2006 [viewed 10 December 2013]. Controle biológico: na busca pela sustentabilidade da agricultura brasileira. Revista Campo e Negócios [online], pp. 66-67. Available from: http://www.cnpab.embrapa.br/publicacoes/artigos/artigo controle biologico.html

MORENO, C.E., 2001. Métodos para medir la biodiversidade. Zaragoza: Unesco \& SEA. 84 p. vol. 1.

OLIVEIRA, J.V., FREITAS, T.F.S., FIUZA, L.M., MENEZES, V.G. and DOTTO, G., 2010. Manejo de insetos associados à cultura do arroz irrigado. Cachoeirinha: IRGA/Estação Experimental. Seção de Agronomia.

PEREIRA, D.P., BANDEIRA, D.L. and QUINCOZES, E.R.F., 2005 [viewed 22 November 2013].. Cultivo do arroz irrigado no Brasil [online]. Brasília: Embrapa Clima Temperado. Available from: http://sistemasdeproducao.cnptia.embrapa.br/FontesHTML/ Arroz/ArrozIrrigadoBrasil/index.htm

SANTOS, R.S.S., REDAELLI, L.R., DIEFENBACH, L.M.G., ROMANOWSKI, H.P., PRANDO, H.F. and ANTOCHEVIS, R.C., 2006. Seasonal abundance and mortality of Oebalus poecilus (Dallas) (Hemiptera: Pentatomidae) in a hibernation refuge. Brazilian Journal of Biology $=$ Revista Brasileira de Biologia, vol. 66, no. 2A, pp. 447-453. http://dx.doi.org/10.1590/S151969842006000300010. PMid:16862299.

SOUZA, L., BRAGA, S.M.P. and CAMPOS, M.J.O., 2006. Himenópteros parasitoides (Insecta, Hymenoptera) em área agrícola de Rio Claro, SP, Brasil. Arquivos do Instituto Biológico, vol. 73, pp. 465-469.

YASUMATSU, K. and TORH, T., 1968. Impact of parasites, predators, and diseases on rice pests. Annual Review of Entomology, vol. 13, no. 1, pp. 295-324. http://dx.doi.org/10.1146/annurev. en.13.010168.001455. 